\title{
Utilization History of Emergency Medical Services Among West Virginia Drug Overdose Decedents
}

\section{Ada Okorie}

Office of Maternal, Child, and Family Health, West Virginia Department of Health and Human Resources, Charleston, West Virginia, United States

Objective

Opioid and illicit substance abuse continues to have major public health implications in the state of West Virginia. By analyzing the Emergency Medical Service (EMS) utilization history of drug overdose decedents, opportunities to improve surveillance of fatal and non-fatal drug overdoses can be identified which can help lead prevention efforts of fatal drug overdoses in the state.

\section{Introduction}

West Virginia continues to lead the nation in drug overdose deaths per capita. In 2016, the age-adjusted rate of drug overdose deaths was 52 per 100,000 [1]. In the same year, there were roughly 64,000 overdose deaths in the United States, a $21.5 \%$ rate increase from 2015 [1]. The drug overdose epidemic in West Virginia has taken a significant toll on individuals, families, communities, and resources.

As part of a rapid response plan to help reduce the burden of overdose deaths, the West Virginia Department of Health and Human Resources conducted an investigative report to study 830 overdose related deaths that occurred in 2016 and identify opportunities for intervention in the 12 months prior to death. Utilization of EMS among decedents was analyzed to determine demographic differences between decedents at different time points of EMS contact: EMS contact at death only; EMS contact 12 months prior to death only; and both EMS contact at death and 12 months prior to death.

\section{Methods}

A list of decedents that had died in 2016 from a drug overdose was obtained from the West Virginia Vital Registration Office and then matched to EMS ambulance run data. The inclusion criteria for this decedent sample were: state residency, drug overdose as the primary cause of death, and a history of EMS utilization. Overall, 588 West Virginia overdose decedents were identified for analysis.

Drug classes, identified by forensic toxicology reports, and demographic information including gender, age, race, marital status, education level, and occupation of each decedent were analyzed to identify trends related to overdose deaths.

A 'death run' was defined as an EMS run that occurred within 48 hours of death. A 'prior EMS run' was defined as an EMS run that occurred within 12 months prior to death.

\section{Results}

Among decedents with an EMS contact, 50\% (N=295) of decedents' only contact was at death. Of the remaining half of decedents with an EMS contact: One-third $(\mathrm{N}=195)$ had both a previous EMS run in the 12 months prior to death and at death; and $17 \%$ $(\mathrm{N}=98)$ of decedents only EMS contact was in the year prior to death that was not a fatal run (Table 1).

There were gender differences in EMS utilization among male and female decedents at death run only, 12 months prior to death only, and at both time points. When comparing time points, the largest percentage of EMS contact among males and females occurred at death run only; although males $(53 \% \mathrm{n}=206)$ had more contact with EMS at death run only compared to females $(45 \%$, $\mathrm{n}=89)$. However among those that had utilized EMS at both time points, females had more encounters with EMS $(38.3 \%$, $n=75)$ than male decedents $(30.61 \%, \mathrm{n}=120)$ (Table 1$)$.

Decedents aged 15-24 years $(64.5 \%, \mathrm{n}=20)$ had the largest percentage of EMS utilization at death run only compared to the other age groups. Decedents aged 65 years and older of prior EMS runs (50.0\%), compared to other age groups (Table 1).

SDS Annual Conference Proceedings 2019. This is an Open Access article distributed under the terms of the Creative Commons AttributionNoncommercial 4.0 Unported License (http://creativecommons.org/licenses/by-nc/3.0/), permitting all non-commercial use, distribution, and reproduction in any medium, provided the original work is properly cited. 
Of the decedents that received at least one naloxone administration in their EMS history ( $\mathrm{n}=178)$, decedents that utilized EMS at both time points received the largest administration at $44 \%(n=80)$. This was followed by $41 \%(n=73)$ of decedents that had EMS contact at death only.

\section{Conclusions}

For half of the decedents analyzed, their only encounter with EMS was associated with their death. This could be explained by the type of drugs that contributed to their deaths, as stronger illicit and/or pharmaceutical drugs such as fentanyl, contributed to more overdose deaths in this population than other drug types [2]. Although decedents aged 15-24 years had highest EMS contact at death run only, illicit drugs were more commonly found in this particular group than other age groups [2].

Evidence has shown that a prior non-fatal overdose in the past, increases the risk of a fatal overdose in the future [3]. One-third $(n=195)$ of decedents in this analysis had both a prior contact with EMS in the year before death and within 48 hours of death. However, it is unknown whether their previous contacts with EMS was associated with an overdose. Further investigation into chief complaints of EMS runs would need to be done to assess the association between prior EMS contact due to a non-fatal overdose and risk of a subsequent fatal overdose.

In this analysis, women had a larger percentage of EMS contact at both time points than men. Studies have indicated that women are more at risk than men for having a fatal overdose [4]. One possibility is that the concurrent use of opioid prescription and illicit drugs, occurs more often among women than in men elevating their risk of having non-fatal and fatal overdoses.

Identifying high-risk individuals with previous overdoses can help to minimize the gap between overdose and accessibility to treatment services. As part of the rapid response plan, the West Virginia Drug Control Policy Act was passed to improve drug overdose surveillance and help strengthen response [5]. The policy enacted the creation of a central repository that will store drug overdose information, making drug overdoses a notifiable condition.

\section{Acknowledgement}

This abstract was prepared in collaboration with the West Virginia Violence and Injury Prevention Program of the West Virginia Department of Health and Human Resources with support from the Centers for Disease Control and Prevention grant: Prescription Drug Overdose for States Program (NU17CE002735-02-03). Its contents are solely the responsibility of the authors and does not represent the official views of the CDC.

\section{References}

1. Seth P, Scholl L, Rudd RA, Bacon S. 2018. Overdose Deaths Involving Opioids, Cocaine, and Psychostimulants - United States, 2015-2016. MMWR Morb Mortal Wkly Rep. 67, 349-58. PubMed https://doi.org/10.15585/mmwr.mm6712a1

2. West Virginia Violence and Injury Prevention Center. 2016 WV Overdose Fatality Analysis: Healthcare Systems Utilization, Risk Factors, and Opportunities for Intervention. 2017 Dec 20.

3. Stoové MA, Dietze PM, Jolley D. 2009. Overdose deaths following previous non-fatal heroin overdose: record linkage of ambulance attendance and death registry data. Drug Alcohol Rev. 28(4), 347-52. PubMed https://doi.org/10.1111/j.1465-3362.2009.00057.x

4. Evans E, Kelleghan A, Li L, Min J, Huang D, et al. 2015. Gender differences in mortality among treated opioid dependent patients. Drug Alcohol Depend. 155, 228-35. PubMed https://doi.org/10.1016/j.drugalcdep.2015.07.010

5. West Virginia Legislature. West Virginia Drug Control Policy Act [Internet]. 2017. Available from: http://www.wvlegislature.gov/Bill_Status/bills_text.cfm? billdoc=HB2620 SUB ENR.htm\&yr=2017\&sesstype=RS\&billtype=B\&houseorig=H\&i=2620.

Table 1. EMS History of 2016 Overdose Decedent Population 


\section{OJPHI}

ISDS 2019 Conference Abstracts

ISDS

NTERNATIONAL SOCIETY

\begin{tabular}{|c|c|c|c|c|c|c|}
\hline & $\begin{array}{l}\text { All Drug } \\
\text { Overdose } \\
\text { Decedents } \\
(\mathrm{N}=830)\end{array}$ & $\begin{array}{l}\text { West Virginia } \\
\text { Population } \\
\text { (Ages 15+) }\end{array}$ & $\begin{array}{l}\text { EMS Run - } \\
\text { Any History } \\
\qquad(\mathrm{N}=588)\end{array}$ & $\begin{array}{l}\text { EMS Run - Within } 12 \\
\text { months prior to death } \\
\qquad(\mathrm{n}=98)\end{array}$ & $\begin{array}{c}\text { EMS Run - } \\
\text { Within } 48 \text { hours of } \\
\text { death }(n=295)\end{array}$ & $\begin{array}{l}\text { EMS Run - Within } 12 \text { months prior } \\
\text { AND within } 48 \text { hours of death } \\
\qquad(\mathrm{n}=195)\end{array}$ \\
\hline Sex & & & & & & \\
\hline Males & $\begin{array}{r}67.11 \% \\
(557)\end{array}$ & $\begin{array}{c}51.00 \% \\
(912,270)\end{array}$ & $\begin{array}{r}70.40 \% \\
(392)\end{array}$ & $\begin{array}{c}16.84 \% \\
(66)\end{array}$ & $\begin{array}{c}52.55 \% \\
(206)\end{array}$ & $\begin{array}{c}30.61 \% \\
(120)\end{array}$ \\
\hline Females & $\begin{array}{r}32.90 \% \\
(273)\end{array}$ & $\begin{array}{r}49.00 \% \\
(933,822)\end{array}$ & $\begin{array}{r}71.80 \% \\
(196)\end{array}$ & $\begin{array}{c}16.33 \% \\
(32)\end{array}$ & $\begin{array}{c}45.41 \% \\
(89)\end{array}$ & $\begin{array}{c}38.27 \% \\
(75)\end{array}$ \\
\hline Total & $\begin{array}{c}100.00 \% \\
(830)\end{array}$ & $\begin{array}{c}100.00 \% \\
(1,846,092)\end{array}$ & $\begin{array}{r}70.80 \% \\
(588)\end{array}$ & $\begin{array}{c}16.67 \% \\
(98)\end{array}$ & $\begin{array}{c}50.17 \% \\
(295)\end{array}$ & $\begin{array}{c}33.16 \% \\
(195)\end{array}$ \\
\hline $\begin{array}{c}\text { Age } \\
\text { (years) }\end{array}$ & & & & & & \\
\hline $15-24$ & $\begin{array}{c}6.62 \% \\
(55)\end{array}$ & $\begin{array}{r}13.00 \% \\
(235,043)\end{array}$ & $\begin{array}{c}56.36 \% \\
(31)\end{array}$ & $\begin{array}{c}6.45 \% \\
(*)\end{array}$ & $\begin{array}{c}64.52 \% \\
(20)\end{array}$ & $\begin{array}{c}29.03 \% \\
(*)\end{array}$ \\
\hline $25-34$ & $\begin{array}{r}22.65 \% \\
(188)\end{array}$ & $\begin{array}{r}12.00 \% \\
(218,633)\end{array}$ & $\begin{array}{r}67.02 \% \\
(126)\end{array}$ & $\begin{array}{c}18.25 \% \\
(23)\end{array}$ & $\begin{array}{c}43.65 \% \\
(55)\end{array}$ & $\begin{array}{c}38.10 \% \\
(48)\end{array}$ \\
\hline $35-44$ & $\begin{array}{r}28.67 \% \\
(238)\end{array}$ & $\begin{array}{r}12.00 \% \\
(228,148)\end{array}$ & $\begin{array}{r}72.27 \% \\
(172)\end{array}$ & $\begin{array}{c}13.37 \% \\
(23)\end{array}$ & $\begin{array}{c}54.07 \% \\
(93)\end{array}$ & $\begin{array}{c}32.56 \% \\
(56)\end{array}$ \\
\hline $45-54$ & $\begin{array}{r}25.42 \% \\
(211)\end{array}$ & $\begin{array}{r}14.00 \% \\
(252,328)\end{array}$ & $\begin{array}{r}79.15 \% \\
(167)\end{array}$ & $\begin{array}{c}16.17 \% \\
(27)\end{array}$ & $\begin{array}{c}52.10 \% \\
(87)\end{array}$ & $\begin{array}{c}31.74 \% \\
(53)\end{array}$ \\
\hline $55-64$ & $\begin{array}{r}14.22 \% \\
(118)\end{array}$ & $\begin{array}{r}15.00 \% \\
(269,885)\end{array}$ & $\begin{array}{c}71.19 \% \\
(84)\end{array}$ & $\begin{array}{c}22.62 \% \\
\text { (19) }\end{array}$ & $\begin{array}{c}45.24 \% \\
(38)\end{array}$ & $\begin{array}{c}32.14 \% \\
(27)\end{array}$ \\
\hline $65+$ & $\begin{array}{c}2.41 \% \\
(20)\end{array}$ & $\begin{array}{r}18.00 \% \\
(328,124)\end{array}$ & $\begin{array}{c}44.40 \% \\
(*)\end{array}$ & $\begin{array}{c}50.00 \% \\
(*)\end{array}$ & $\begin{array}{c}10.00 \% \\
(*)\end{array}$ & $\begin{array}{c}25.00 \% \\
(*)\end{array}$ \\
\hline
\end{tabular}

*data suppressed due to low count 